\title{
ANALISIS TATA KELOLA TEKNOLOGI INFORMASI MENGGUNAKAN FRAMEWORK COBIT 5 DOMAIN EDM
}

\author{
Murry Aryo Wicaksono ${ }^{1}$, Yani Rahardja ${ }^{2}$, Hanna Prillysca Chernovita ${ }^{3}$ \\ ${ }^{1,2,3}$ Program Studi Sistem Informasi Fakultas Teknologi Informasi Universitas Kristen Satya Wacana \\ Jln. Dr.O.Notohamidjodjo, Blotongan, Sidorejo, Kota Salatiga, 50715 \\ 1682015075@student.uksw.edu \\ ${ }^{2}$ yani.rahardja@uksw.edu \\ 33anna.chernovita@uksw.edu
}

\begin{abstract}
Abstrak - Dinas Kependudukan dan Catatan Sipil Kota Tangerang menggunakan sumber daya teknologi informasi untuk mempermudah dalam melakukan aktivitas pelayanan kepada masyarakat. Untuk mengetahui sudah sejauh mana tata kelola teknologi informasi berjalan maka dilakukan pengukuran tingkat kapabilitas tata kelola TI yang telah diterapkan . Tujuan dari dilakukannya pengukuran ini adalah untuk mengetahui sudah sampai dimanakah level kemampuan tata kelola TI yang telah diterapkan , sehingga dapat diberikan rekomendasi untuk meningkatkan kinerja perusahaan tersebut . Penelitian ini menggunakan pendekatan mix method ,dimana pengumpulan data dilakukan dengan cara observasi dan wawancara. Dari hasil pengumpulan data berdasarkan framework COBIT 5 didapat pengoptimalan tata kelola TI yang berjalan (EDM01) pada saat ini berada di level 3 (managed process) dengan status pencapaian largely achieved sebesar $65 \%$. Untuk proses pengoptimalan pelayanan manajerial (EDM02) saat ini berada pada level 4 (Predictable process) dengan status pencpaian largely achieved sebesar $65 \%$. Proses pengelolaan resiko (EDM03) saat ini berada di level 3 (established process) dengan ststus pencapaian largely achieved sebesar $65 \%$. Proses optimalisasi sumber daya (EDM04) saat ini berada pada level 3 (established process) dengan pencapaian partially achieved sebesar $45 \%$. Untuk Proses optimalisasi kinerja (EDM05) saat ini berada pada level 5 (optimizing process) dengan status pencapaian fully achieved sebesar $100 \%$
\end{abstract}

Kata Kunci : Tata Kelola TI , Pengukuran tingkat kapabilitas , COBIT 5 , Domain EDM01, EDM02,EDM03,EDM04,EDM05

\section{Pendahuluan}

Teknologi Informasi (TI) merupakan aset yang terpenting yang harus dimiliki oleh setiap organisasi karena dapat membantu meningkatkan efektivitas dan efisiensi kinerja dari organisasi tersebut. Setiap organisasi perlu menerapkan, memanfaatkan, dan mengembangkan, sumber daya TI yang dimiliki untuk menunjang kinerja dalam mencapai tujuan organisasi. Oleh sebab itu dibutuhkan mekanisme tata kelola yang tepat agar dapat melakukan pengawasan, pemantauan, dan evaluasi secara menyeluruh agar setiap mekanisme dan manajemen TI yang sedang berjalan sesuai dengan perencanaan, kinerja, dan tujuan organisasi. Salah satu kerangka kerja atau framework yang digunakan untuk mengukur tingkat kematangan tata kelola IT adalah COBIT 5.

Disdukcapil Kota Tangerang adalah lembaga Pemerintahan yang memiliki tugas melaksanakan urusan pemerintahan daerah berdasarkan asas otonomi dan tugas pembantuan di bidang kependudukan dan pencatatan sipil serta tugas lain yang diberikan Walikota sesuai dengan lingkup tugas dan fungsinya. Disdukcapil dibagi beberapa bidang pekerjaan, yaitu Sekreteriat, Bidang Program, Bidang Pendaftaran Dan Informasi Penduduk, Bidang Pencatatan Sipil, dan Bidang Pengendalian Penduduk.

Kegiatan yang dilakukan di Disdukcapil tidak jauh dari pengolahan data kependudukan, dimana hasil atau output data tersebut akan diunggah pada web Disdukcapil Kota Tangerang. Dalam proses pengolahan data tersebut, dibutuhkan perangkat TI yang baik agar proses operasional dapat berjalan dengan baik. Namun dari pengamatan yang telah dilakukan, masih ada beberapa permasalahan seperti server yang sering down atau overload sehingga berakibat pada proses tunggu yang lama. Selain itu, jaringan internet juga menjadi kendala, dimana bandwidth yang digunakan tidak sebanding dengan 
jumlah perangkat komputer yang ada sehingga pada saat proses upload akan membutuhkan waktu yang cukup lama. Hal tersebut tentu sangat membebani karyawan yang harus melakukan penginputan ulang dan membuat waktu menjadi sia - sia karena seharusnya dapat digunakan untuk melakukan penginputan data selanjutnya atau melakukan pekerjaan yang lain. Dari permasalahan tersebut bisa dikatakan proses monitoring operasional IT belum berjalan sesuai dengan yang diharapkan

Proses pengolahan data kependudukan dilakukan selama 24 jam tergantung seberapa besar data yang akan diolah oleh beberapa karyawan yang membantu dalam proses operasional, tentunya dengan pengawasan penuh dari bagian IT. Proses tersebut akan membuat perangkat keras atau hardware bekerja secara penuh yang bisa berakibat pada kerusakan. Investasi dalam bidang TI tentunya memerlukan biaya yang cukup besar dan juga bila memperhatikan perawatannya. Perawatan secara berkala sangat penting, sebab jika hal tersebut tidak dilakukan maka investasi tersebut akan menjadi sia - sia dan dapat merugikan dalam proses operasional. Jika tidak dilakukan proses monitoring pada aktivitas operasional maka akan menghambat kinerja. Maka perlu dilakukannya proses monitoring pada operasional agar memberikan dampak positif bagi kinerja organisasi .

Evaluasi kinerja Teknologi Informasi secara umum dapat dilakukan dengan menggunakan kerangka kerja atau framework COBIT. Kerangka kerja COBIT (Control Objectives for Information and Related Technology) merupakan suatu kerangka kerja tata kelola dan manajemen teknologi informasi yang diciptakan oleh ISACA (Information System Audit and Control) dan ITGI (IT Governance Institute). Framework COBIT 5 mencakup tujuan pengendalian yang terdiri dari 5 (lima) domain, yaitu: Domain EDM (Evaluating, Direction, and Monitoring), Domain APO ( Align, Plan, Organise), Domain BAI (Build, Acquire, and Implement), Domain DSS (Deliver, Service and Support), dan Domain MEA (Monitoring, Evaluate, and Asses). Selain itu COBIT 5 memiliki model kapabilitas (capability model) yang bertujuan untuk mencapai tujuan secara keseluruhan dari proses penilaian dan proses dukungan perbaikan, yaitu untuk menyediakan sarana untuk mengukur kinerja dari setiap sisi tata kelola TI yang kemudian diterapkan pada suatu penilaian kapabilitas proses . Maka dari itu diperlukan evaluasi pada pengelolaan Teknologi Informasi yang sedang berjalan. Tujuan dari evaluasi adalah untuk memberikan rekomendasi terhadap keadaan tata kelola teknologi informasi pada proses monitoring operasional TI di Dinas Kependudukan Dan Catatan Sipil Kota Tangerang untuk saat ini, dan juga dapat memberikan strategi yang berguna untuk perbaikan pengelolaanya di masa yang akan datang.

Penelitian dengan judul "Analisis Tata Kelola Teknologi Informasi Menggunakan Framework COBIT 5 (Studi Kasus Dinas Kependudukan Dan Catatan Sipil Kota Tangerang) bertujuan untuk Melakukan pengukuran tingkat kematangan (maturity level) tata kelola Teknologi Informasi yang ada di Dinas Kependudukan Dan Catatan Sipil Kota Tangerang serta Melakukan pengukuran tingkat penerapan sistem informasi pada Dinas Kependudukan Dan Catatan Sipil Kota Tangerang berdasarkan perspektif menggunakan standar COBIT 5 domain EDM (Evaluate, Direct, and Monitor) untuk untuk mengukur tingkat kapabilitas tata kelola TI yang sedang berjalan di Disdukcapil Kota Tangerang. Hasil dari penelitian ini diharapkan mampu memberikan temuan-temuan dan rekomendasi terkait dengan proses monitoring operasional TI bagi Dinas Kependudukan Dan Catatan Sipil Kota Tangerang untuk menjaga efektifitas dan efisiensi kinerja seperti yang telah dirancang sebagai tujuan dari organisasi .

Analisis terhadap tata kelola TI menggunakan kerangka kerja COBIT terhadap suatu instansi telah banyak dilakukan dalam berbagai jenis penelitian. Dari penelitian tersebut didapat suatu rekomendasi yang dapat digunakan untuk memperbaiki tata kelola TI yang sudah atau sedang berjalan di perusahaan maupun instansi terkait. Dalam hal ini penulis juga menggunakan penelitian terdahulu sebagai acuan. Penelitian pertama berjudul Analisis Tata Kelola Teknologi Informasi menggunakan Kerangka Kerja COBIT 5 Pada AMIK JTC Semarang yang membahas tentang implementasi framework COBIT 5 dalam mengidentifikasi proses TI yang sudah berjalan di instansi tersebut apakah sudah berjalan dan terkelola dengan baik dan juga dilakukan identifikasi terhadap kondisi yang diharapkan di masa mendatang. Penelitian ini mencakup domain proses evaluate, direct and monitor; align, plan, and organize; dan build, acquire and implement. Hasil dari penelitian yang dilakukan adalah memberi gambaran bahwa berdasarkan pemetaan antara tujuan bisnis dan rencana strategis AMIK tahun 2010 2014 terdapat 20 dari 37 domain proses yang menjadi fokus utama penelitian yang terbagi atas 4 domain. Selain itu berdasarkan analisis yang telah dilakukan, didapat nilai capability level pada level 1 (Performed process) yang menyatakan bahwa setiap proses TI di AMIK sudah berjalan dengan baik dan sudah mencapai tujuan yang ingin dicapai. Sedangkan pada level expectation yang diharapkan ada pada level 2 (Managed process) dan terdapat 6 proses yang diharapkan dapat mencapai level 3 [1] .

Kedua, penelitian yang berjudul Analisis Tata Kelola Teknologi Informasi di PDAM Kota Salatiga Menggunakan Framework COBIT 5 Dengan Domain EDM yang menjelaskan tentang bagaimana proses tata kelola yang ada di PDAM kota Salatiga yang sudah berjalan serta sudah sampai manakah tingkat kematangan kondisi kematangan infrastruktur TI yang berada di instansi tersebut. Penelitian tersebut mencakup domain EDM (Evaluate, direct, and monitor). Hasil dari penelitian tersebut adalah tingkat kematangan TI di PDAM Salatiga berada pada level 3 (managed process). Hasil tersebut masih jauh dari target 
pencapaian yang diinginkan, yaitu pada level 5 (optimizing process) [2] .

Penelitian yang ketiga berjudul Analisis Tata kelola Teknologi Informasi Dengan Menggunakan Framework COBIT 5 domain DSS01 (Manage Operations) Pada BPS Provinsi Jawa Tengah. Penelitian tersebut membahas tentang pengukuran tingkat kapabilitas TI di BPS Jawa Tengah menggunakan framework COBIT 5 subdomain deliver, service and support 01 (DSS01). Hasil yang didapat dari penelitian tersebut adalah pencapaian tingkat kapabilitas tata kelola TI terkait proses monitoring operasional TI pada BPS Provinsi Jawa Tengah berada pada level 1. Artinya banyak yang harus diperbaiki agar dapat mencapai tingkat kapabilitas minimal pada level 3 (established) [3].

Tata kelola (governance) merupakan kombinasi antara proses dan struktur yang diterapkan oleh pihak pimpinan dan eksekutif dari sebuah organisasi untuk menginformasikan, mengarahkan, mengelola, dan memantau kegiatan organisasi dalam rangka pencapaian tujuan sebuah organisasi. Adapun teknologi informasi (TI) merupakan suatu studi perancangan, implementasi, pengembangan, dukungan atau manajemen sistem informasi berbasis komputer, khususnya perangkat keras (hardware) dan perangkat lunak (software). Sedangkan tata kelola teknologi informasi (IT Governance) merupakan merupakan suatu bentuk perencanaan dalam menerapkan dan menggunakan TI yang digunakan oleh suatu perusahaan agar sesuai dengan visi, misi dan tujuan dari organisasi.

Berdasarkan pengertian di atas, dapat diartikan bahwa tata kelola teknologi informasi merupakan sebuah struktur perencanaan yang dijadikan pedoman pimpinan maupun eksekutif sebuah organisasi untuk melakukan pengelolaan terhadap sumber daya teknologi informasi yang ada pada perusahaan tersebut, sekaligus menyelaraskan, mengembangkan, dan memperluas strategi TI agar dapat berjalan sesuai dengan tujuan dan visi misi organisasi guna menunjang keberhasilan organisasi di masa mendatang.

Adapun kegunaan dari tata kelola teknologi informasi adalah untuk mengatur penggunaan sumber daya TI, serta untuk memastikan agar kinerja TI sesuai dengan tujuannya yaitu: 1) memastikan keselarasan TI dengan strategi organisasi serta terkait dengan perealisasian dari keuntungankeuntungan yang telah dijanjikan dari penerapan TI; 2) memungkinkan perusahaan pengguna TI untuk dapat mengambil peluang yang ada serta memaksimalkan keuntungan dari penerapan TI tersebut; 3) bertanggung jawab terhadap penggunaan sumber daya TI; 4) dapat memanajemen resiko yang ada terkait TI secara tepat [4] .

Penelitian ini mengaplikasikan framework COBIT 5 yang berguna untuk mengukur tingkat kematangan sebuah Teknologi Informasi. Kerangka kerja COBIT 5 merupakan standar yang dinilai lengkap dengan cakupan yang menyeluruh sebagai sebuah framework audit.
Kerangka kerja COBIT 5 juga merupakan kerangka kerja tata kelola dan manajemen TI yang efektif karena dapat membantu organisasi dalam mencapai tujuan bisnis, serta dapat mengoptimalkan investasi, tingkat resiko dan penggunaan TI sehingga memberikan keuntungan bagi stakeholder. Kerangka kerja COBIT 5 memungkinkan pengembangan kebijakan yang jelas dan praktek yang baik untuk kontrol teknologi informasi di dalam organisasi.

Pengukuran kinerja manajemen TI perlu mengidentifikasi, mengetahui, dan menyelaraskan kemampuan serta kekurangan yang dimiliki oleh organisasi saat ini guna melakukan evaluasi dan penilaian kemampuan dengan menganalisis gap yang ada dan menetapkan target kemampuan untuk proses yang dipilih, serta dapat memberikan rekomendasi dan solusi perbaikan untuk meningkatkan kebutuhan dalam menunjang keberhasilan organisasi.

Kerangka kerja COBIT 5 memiliki lima cakupan domain yaitu Domain EDM (Evaluating, Direction and Monitoring), Domain APO ( Align, Plan and Organize), Domain BAI (Build, Acquire and Implement), Domain DSS (Deliver, Service and Support), dan Domain MEA (Monitoring, Evaluate, and Asses). Domain EDM terdiri dari 5 (lima) proses yaitu EM01 (Ensure governance framework setting and maintenance), EDM02 (Ensure benefits delivery), EDM03 (Ensure risk optimization), EDM04 (Ensure resource optimization), dan EDM05 (Ensure stakeholder Transparency). Domain APO (Align, Plan and Organize) terdiri dari 13 (tiga belas) proses yaitu APO01 (Manage The IT Management framework), APO02 (Manage strategy), APO03 (Manage enterprise architecture), APO04 (Manage innovation), APO05 (Manage portfolio), APO06 (Manage budget and costs), APO07 (Manage human resource), APO08 (Manage relationships), APO09 (Manage service agreements), APO10 (Manage supliers), APO11 (Manage quality), APO12 (Manage risk), dan APO13 (Manage security). Domain BAI (Build, Acquire and Implement) terdiri dari 10 (sepuluh) proses yaitu BAI01 (Manage programs and projects), BAI02 (Manage requirementsdefinition), BAI03 (Manage solutions identification and build), BAI04 (Manage availibility and capacity), BAI05 (Manage operasional change enablement), BAI06 (Manage changes), BAI07 (Manage changes acceptance and transitioning), BAI08 (Manage knowledge), BAI09 (Manage assets), BAI10 (Manage configuration). Domain DSS (Deliver, Service and Support) terdiri dari 6 (enam) proses yaitu DSS01 (Manage Operations), DSS02 (Manage service requests and incidents), DSS03 (Manage problems), DSS04 (Manage continuity), DSS05 (Manage security services), dan DSS06 (Manage business process control). Domain MEA (Monitor, Evaluate and Assess) terdiri dari 3 (tiga) proses yaitu MEA01 (Monitor, evaluate and assess performance and conformance), MEA02 (Monitor, evaluate and assess the system of internal control), MEA03 
(Monitor, evaluate and assess compliance with external requirements) [5].

Pemilihan kerangka kerja COBIT 5 sangat sesuai untuk melakukan audit TI karena mampu mencakup semua elemen tata kelola TI dengan tidak terpusat hanya masalah teknis dan teknologi saja tetapi juga mengidentifikasi sumber daya lainnya yang menjadi penggerak tata kelola TI untuk menuju tujuan organisasi. Terkait dengan analisis terhadap tata kelola TI, COBIT 5 menyediakan ukuran, indikator, proses dan kumpulan praktik terbaik untuk membantu instansi lebih optimal dari pengolahan teknologi informasi. Selain itu COBIT juga berlaku untuk pengembangan terhadap pengendalian terhadap manajemen teknologi informasi yang pantas untuk suatu organisasi.

Ada beberapa metode yang digunakan untuk mengukur kinerja suatu sistem teknologi informasi seperti tingkat kematangan (maturity level), model kapabilitas proses (Capability Process Model), dan analisis kesenjangan (Gap Analysis). Maturity Model merupakan salah satu metode yang digunakan untuk mengukur level atau tingkat perkembangan proses manajemen yang berjalan berdasarkan pencapaian terhadap tujuan perusahaan. Dengan pengukuran tingkat kematangan TI dapat memperlihatkan perkembangan guna mengurangi resiko sekaligus meningkatkan efisiensi kinerja terkait sumber daya, biaya, maupun TI yang ada. Tingkat kematangan untuk pengelolaan dan pengendalian pada proses TI didasarkan pada metode evaluasi organisasi sehingga dapat melakukan proses evaluasi sendiri dimulai dari level 0 (non-existent/tidak ada) hingga level 5 (Optimized). Tingkat kematangan tersebut dimaksudkan untuk mengetahui permasalahan atau resiko yang ada dan bagaimana menentukan peningkatan utama tata kelola TI. Tingkat kematangan dirancang sebagai profil proses teknologi informasi, sehingga organisasi akan dapat mengenalinya sebagai deskripsi kemungkinan keadaan sekarang dan di masa yang akan datang [6].

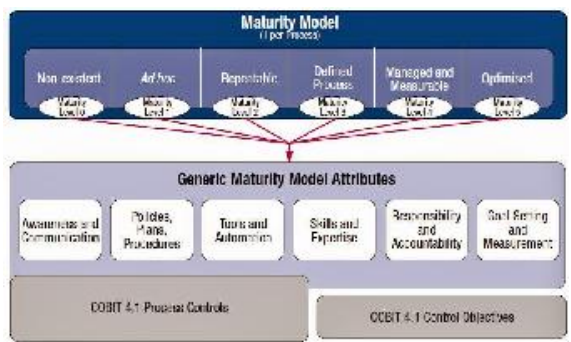

Gambar 1 . Maturity Model [5]

Model Kapabilitas Proses (Process Capability Model) memiliki 6 tingkat model kapabilitas dan sembilan atribut proses berdasarkan pencapaian proses tersebut, dimana level 0 menunjukkan keberadaan pencapaian tujuan proses tersebut. Kegiatan evaluasi adalah proses pemetaan untuk level 1 dengan demikian level yang lebih tinggi yang selanjutnya akan diraih. Karena hasil dari level 1 merupakan penentuan apakah proses tersebut sudah mencapai tujuan, maka hal tersebut sangat penting untuk dicapai yang dimana berdasarkan tiap pencapaian level akan menjadi pondasi untuk dapat mencapai level yang lebih tinggi [5].

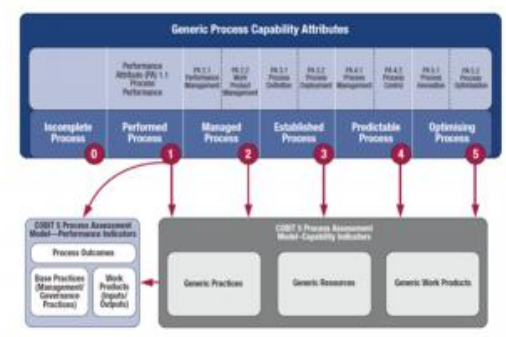

Gambar 2 . Model Kapabilitas Proses Dalam COBIT 5 [6]

Berdasarkan gambar 2, pengukurann kapabilitas di setiap prosesnya dibedakan menjadi 6 (enam) tingkatan yang dapat dicapai oleh masing - masing proses, yaitu :

- Incomplete Process (Level 0), proses tidak diterapkan atau gagal untuk mencapai tujuan yang telah direncanakan.

- Performed Process (Level 1), proses telah diterapkan dan mencapai tujuan yang telah direncanakan.

- $\quad$ Managed Process (Level 2), proses telah dijelaskan sebelumnya, sekarang diterapkan dalam situasi pengelolaan (direncanakan, dimonitor, dan disesuaikan) dan produk kerjanya secara tepat ditetapkan, dikendalikan dan dipelihara.

- $\quad$ Established Process (Level 3), proses yang dikelola telah dideskripsikan sebelumnya, sekarang telah diterapkan menggunakan proses yang didefinisikan sehingga mampu mencapai hasil prosesnya

- Predictable Process (Level 4), proses yang telah ditetapkan sebelumnya untuk dilakukan pengembangan secara berkesinambungan untuk memenuhi tujuan bisnis yang relevan untuk saat ini dan proyeksi mendatang.

- Optimizing Process (Level 5), proses yang telah diterapkan sebelumnya dilakukan pengembangan secara berkesinambungan untuk memenuhi tujuan bisnis yang relevan saat ini dan proyeksi mendatang.

Skala penilaian di setiap levelnya dapat diklasifikasikan sebagai berikut :

- N: Not achieved/tidak tercapai (proses hanya dijalankan 0-15\%);

- P: Partially achieved/tercapai sebagian (proses dijalankan 15-50\%);

- L: Largerly achieved/secara garis besar tercapai (proses dijalankan 50-85\%);

- F: Fully achieved/tercapai penuh (proses dijalankan 85-100\%). 
Sebuah proses yang sedang berjalan dapat dinyatakan mencapai tingkat kapabilitas tertentu, apabila suatu proses atribut dari proses tersebut dapat mencapai suatu level kapabilitas dengan kategori largely achieved (L) atau fully achieved (F). Proses tersebut dapat melanjutkan penilaian ke level kapabilitas selanjutnya apabila atribut tersebut sudah meraih kategori fully achieved (F). Untuk pengukuran kapabilitas level 1 berdasarkan aktivitas yang terkait dengan manajemen atau tata kelola dan input atau output setiap proses [6].

Sedangkan analisis kesenjangan (Gap Analysis) merupakan suatu metode pengukuran dalam evaluasi kinerja berdasarkan suatu proses yang sedang berjalan terutama dalam manajemen internal perusahaan yang hasilnya dapat digunakan sebagai alat untuk membantu mengukur kualitas sebuah perusahaan dalam tahap perencanaan maupun evaluasi. Gap analysis dalam bidang bisnis dan manajemen diartikan sebagai tolak ukur kinerja aktual yang ditingkatkan untuk memudahkan dalam mengetahui sektor atau bidang yang harus diperbaiki dan ditingkatkan kinerjanya. Berdasarkan hasil perhitungan apabila hasil gap analysis semakin rendah maka dapat diartikan semakin baik kualitas kinerja dari perusahaan tersebut. Adapun beberapa manfaat dari gap analysis [7] :

- Untuk menilai kesenjangan aktual dengan yang diharapkan

- Untuk mengetahui peningkatan kinerja untuk menutup kesenjangan

- Sebagai dasar pengambilan keputusan untuk memenuhi standar

- Untuk mengetahui kondisi saat ini terkait tindakan yang akan dilakukan di masa mendatang.

Untuk mengetahui nilai Gap, tingkat kematangan yang didapat saat ini dan tingkat kematangan yang diharapkan harus diketahui, sehingga dapat dituliskan dengan rumus sebagai berikut:

\section{GAP = Nilai yang diharapkan - Nilai yang didapatkan}

\section{Metodologi Penelitian}

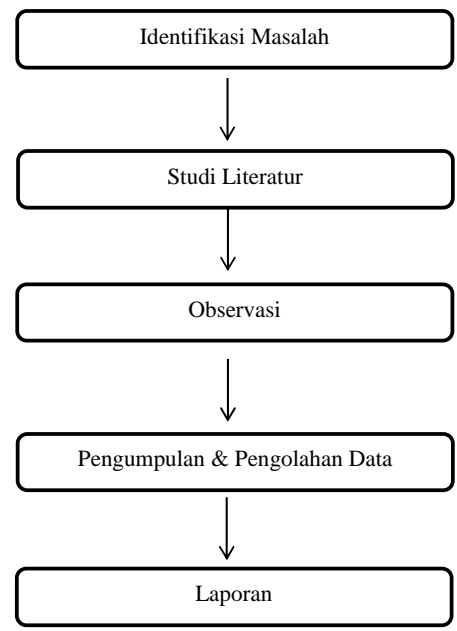

Setelah didapat hasil perhitungan capability level, maka dapat dilakukan analisis kesenjangan apa yang terdapat dari hasil perhitungan tersebut. Dalam penentuan kesenjangan (gap) yang dilakukan dengan menganalisis hasil wawancara dan observasi, kemudian akan menghasilkan kondisi terkini apabila di dalamnya terdapat proses yang belum terpenuhi pada level tingkat kematangan tertentu. Sedangkan pada level dan gap inilah yang kemudian menjadi temuan dari proses penelitian ini.

Tahapan yang terakhir adalah menyusun laporan, yakni dengan melaporkan hasil temuan dan memberikan rekomendasi terhadap organisasi. Rekomendasi merupakan suatu laporan dari hasil pengukuran yang dilakukan terhadap proses tata kelola yang telah ditentukan. Setelah didapat hasil dari capability level, dibuat tabel rekomendasi dan perbaikan untuk mencapai target. Laporan tersebut diperoleh dari hasil analisis terhadap hasil perhitungan capability level dan analisis gap sebagai bentuk perancangan solusi untuk memberikan usulan perbaikan. Usulan perbaikan yang disusun diarahkan agar organisasi dapat mencapai tingkat kematangan sesuai dengan yang diharapkan. Rekomendasi dilakukan dengan memberikan solusi perbaikan untuk proses yang terdapat pada tingkat kematangan.

\section{HASIL DAN PEMBAHASAN}

Dinas Kependudukan Dan Catatan Sipil Kota Tangerang merupakan sebuah instansi pemerintah yang bergerak di bidang administrasi kependudukan. Disdukcapil Kota Tangerang sendiri memiliki beberapa tugas, yakni pembuatan kartu tanda penduduk, akta kelahiran, kartu keluarga, dan lainnya. Disdukcapil Kota Tangerang telah menggunakan, memanfaatkan serta mengembangkan TI dalam memudahkan aktivitas yang sedang berjalan. Adapun penggunaan TI di instansi saat ini telah berjalan sesuai dengan perencanaan, akan tetapi masih terdapat beberapa kendala seperti jaringan internet yang terkadang mengalami gangguan, server yang sering down, keterbatasan jumlah perangkat keras (hardware) dan masih banyak lagi. Oleh karena itu dalam proses pengelolaan TI saat ini dirasa belum cukup optimal apabila dikaitkan dengan sumber daya TI yang ada. Hal ini diperjelas dalam penuturan Bapak Syaiful sebagai staff umum dan bidang personalia di bagian TI pada Disdukcapil berikut ini:

"Penggunaan dan pengelolaan teknologi dan sistem informasi (TI/SI) yang ada di Disdukcapil sudah berjalan sesuai dengan apa yang direncanakan. Namun kami masih memiliki beberapa kendala seperti kondisi infrastruktur teknologi dan sistem informasi, dan dalam pengelolaan dan penggunaan sumber daya TI serta sarana sistem informasi sendiri dirasa masih belum optimal. Misalnya saja server yang sering down atau overload sehingga berakibat pada 
proses tunggu yang lama. Selain itu jaringan internet juga menjadi kendala, dimana bandwidth yang digunakan tidak sebanding dengan jumlah perangkat komputer yang ada sehingga pada saat proses upload membutuhkan waktu yang cukup lama. Untuk proses pengelolaan sumber daya TI dilakukan oleh pihak ke-3, oleh karena itu kami hanya bisa menanggulangi masalah-masalah kecil terkait human error ataupun apabila terdapat kendala pada perangkat hardwarenya. Selanjutnya pihak kami masih kekurangan sumber daya manusia (SDM) yang ahli di bidang TI karena itu kami belum memiliki divisi atau bagian sendiri yang berpusat untuk menangani TI di perusahaan". ${ }^{\prime}$

Dari analisis terhadap temuan-temuan yang ada dalam proses tata kelola di Disdukcapil Kota Tangerang, maka dapat dilakukan evaluasi tata kelola teknologi informasi dengan menggunakan framework COBIT 5. Fokus domain dalam COBIT 5 yang digunakan dalam penelitian ini adalah domain EDM. Proses EDM terbagi menjadi 5 subdomain yaitu: EDM01,EDM02, EDM03, EDM04, dan EDM05. Di mana proses EDM01 (Ensure governance framework setting and maintenance) berfokus pada konsistensi dalam pengintegrasian dan penyelarasan terhadap tata kelola TI yang sedang berjalan di perusahaan. Pada Disdukcapil proses ini telah mencapai level 3 (Managed Process) dengan angka 3.00 dan prosentase $65 \%$ termasuk kategori largely achieved dimana Disdukcapil Kota Tangerang dapat menerapkan tata kelola TI secara konsisten dengan proses yang sudah terdefinisi secara matang serta dapat terintegrasi dan selaras dengan visi misi dan kondisi yang ada di Disdukcapil meskipun masih banyak kekurangan di dalam pengelolaanya, tetapi belum bisa melakukan pengembangan yang berkesinambungan untuk menanggulangi proyeksi di masa yang akan datang. Sementara ini pihak Disdukcapil sendiri telah menjalankan Tata Kelola TI terhadap kondisi perusahaan sebagai penunjang dalam melakukan pengevaluasian terhadap TI yang berjalan disana. Hal ini ditegaskan oleh Bapak Syaiful sebagai berikut:

"Tata kelola TI yang berjalan di Disdukcapil saat ini sudah berjalan secara optimal dan selaras dengan visi misi maupun strategi TI yang ada di Disdukcapil sendiri, namun dalam pelaksanaannya kami masih memiliki kekurangan mengenai penyelarasan dengan strategi TI yang ada sekaligus dalam pengembangan model kami masih tertutup dengan pengevaluasian yang dilakukan, karena dalam hal pengevaluasian dari tim evaluasi pemerintah daerah sebagai pihak yang berwenang dalam proses evaluasi hasil kelola daerah". ${ }^{2}$

\footnotetext{
${ }^{1}$ Berdasarkan hasil wawancara dengan Bapak Syaiful staff umum dan personalia bagian TI pada tanggal 18 September 2019 di Disdukcapil Kota Tangerang

2 Berdasarkan hasil wawancara dengan Bapak Syaiful staff umum dan personalia bagian TI pada tanggal 18 September 2019 di Disdukcapil Kota Tangerang
}

Proses EDM02 (Ensure benefits delivery) berfokus pada optimalisasi kontribusi nilai bisnis dari proses tata kelola, layanan TI dan aset yang dihasilkan dari investasi TI yang dilakukan oleh organisasi dengan anggaran yang efisien. Adapun tujuan dari proses EDM02 adalah mengamankan nilai optimal dari inisiatif pemanfaatan TI (jasa dan aset) dengan cara memberikan solusi dan layanan yang hemat biaya secara akurat dan menentukan proyeksi keuntungannya, sehingga kebutuhan tata kelola yang didukung dapat dicapai secara efektif dan efisien. Dari segi pelayanan sendiri, Disdukcapil sudah memliliki SOP (Standard Operational Procedure) yang sudah terdapat aturan dalam melakukan pelayanan jasa terhadap penduduk. Saat ini proses EDM02 yang berlaku di Disdukcapil telah mencapai level 4 (Predictable Process), dengan nilai sebesar 4,25 dan presentase $65 \%$ jadi masuk ke dalam kategori largely achieved, dimana Disdukcapil telah melakukan pelayanan dan penggunaan aset yang ada secara optimal dan memiliki tolok ukur dalam melakukan proses tata kelola tersebut. Hal tersebut disampaikan langsung oleh Bapak Syaiful sebagai berikut:

"Dari segi pelayanan sendiri sistem yang kami miliki sudah cukup baik, jarang terjadi permasalahan pada bidang pelayanan dan pengaduan."3

Proses EDM03 (Ensure Risk Optimization) merupakan proses yang berfokus pada optimalisasi resiko TI yakni memastikan bahwa resiko yang dapat diterima perusahaan dan toleransinya sudah dipahami, diartikulasikan dan dikomunikasikan, serta resiko perubahan nilai perusahaan terkait dengan penggunasan TI dapat diidentifikasi dan dikelola. Tujuan dari proses EDM03 adalah memastikan bahwa resiko TI perusahaan yang terkait tidak melebihi batas toleransinya. Agar dampak TI yang beresiko pada nilai organisasi dapat diidentifikasi dan dikelola untuk meminimalisasi resiko tata kelola. Pada saat ini proses EDM03 di Disdukcapil berada di level 3 (established process) dengan nilai sebesar 3,56 dan presentase sebesar $65 \%$, dan masuk ke dalam kategori largely achieved. Hal tersebut dikarenakan proses yang dikelola telah dideskripsikan sebelumnya, sekarang telah diterapkan menggunakan proses yang didefinisikan sehingga mampu mencapai hasil prosesnya .Manajemen resiko TI telah berjalan, tetapi masih terdapat kekurangan dalam efisiensi manajemen resiko yang telah berjalan. Hal ini sesuai dengan apa yang disampaikan oleh Bapak Syaiful sebagai berikut:

"Di Disdukcapil sendiri, kami telah melakukan pengelolaan manajemen resiko sesuai dengan strategi TI yang kami miliki. Akan tetapi dalam pelaksanaannya kami masih memiliki kesulitan, khususnya dalam mengelola manajemen resiko yang ada agar tidak melebihi kapasitas yang dapat

\footnotetext{
3 Berdasarkan hasil wawancara dengan Bapak Syaiful staff umum dan personalia bagian TI pada tanggal 18 September 2019 di Disdukcapil Kota Tangerang
} 
kami atasi. Hal tersebut dikarenakan saat ini tidak adanya subdivisi yang mengelola TI secara intensif di Disdukcapil. Oleh sebab itu kami hanya bisa menanggulangi apabila ada masalah yang terjadi sebisa yang kami lakukan terlebih dahulu, baru setelah itu kami dapat melakukan diskusi dengan pihak ketiga sehubungan dengan mereka sebagai pemberi jasa layanan maintenance di bagian TI Disdukcapil saat ini." 4

Proses EDM04 (Ensure resource optimization) berfokus pada optimalisasi sumber daya yakni memastikan bahwa kemampuan yang berkaitan dengan TI cukup memadai (orang, proses dan teknologi) serta tersedia untuk mendukung tujuan perusahaan secara efektif dengan biaya yang optimal. Tujuan dari proses EDM04 adalah memastikan bahwa kebutuhan sumber daya perusahaan terpenuhi dengan cara yang optimal. Biaya TI dioptimalkan, memungkinkan memungkinkan peningkatan realisasi keuntungan serta kesiapan untuk perubahan di masa yang akan datang. Pada Disdukcapil sendiri, proses ini berada di level 3 (Established process) dengan angka 3.33 dan presentase sebesar $45 \%$; atau masuk kedalam kategori partially achieved dimana untuk pengelolaan sumber daya TI sudah dilakukan sesuai dengan prosedur, akan tetapi masih terdapat banyak kekurangan seperti yang disampaikan oleh Bapak Syaiful berikut ini :

"Dalam pemeliharan terhadap perangkat TI dilakukan jika ada kerusakan, atau ada kegiatan pengolahan yang membutuhkan perangkat TI secara besar; sehingga diperlukan pengecekan kelayakan agar dapat diketahui perangkat yang rusak dan harus diganti. Untuk layanan penyimpanan data dan jaringan sudah ada kerjasama dengan pihak ketiga. Untuk memonitor user ada sistem bernama SIPPTI (Sistem Informasi Pelayanan Perangkat Teknologi Informasi). Sistem ini berjalan untuk peminjaman beberapa perangkat TI dan laporan kerusakan dari barang yang dipinjam. Untuk proses monitoring jaringan dipantau oleh staff melalui mikrotik. Untuk bentuk pengamanan di setiap ruangan terdapat perangkat cctv yang dapat dipantau oleh pihak keamanan, juga terdapat alat pencegah kebakaran. Ruang server selalu tertutup dan merupakan ruang tersendiri dengan suhu ruang harus selalu dingin. Untuk ruang server sendiri selalu dikunci sebagai bentuk pengamanannya; meskipun belum ada peraturan yang mendetail tetapi ruangan tersebut selalu diawasi karena berada di ruangan staff IPDS. Jadi, siapa saja yang masuk dan keluar dapat dipantau.

\footnotetext{
4 Berdasarkan hasil wawancara dengan Bapak Syaiful staff umum dan personalia bagian TI pada tanggal 18 September 2019 di Disdukcapil Kota Tangerang
}

Ruang server juga harus dalam keadaan dingin karena harus menyala 24 jam." 5

Proses EDM05 (Ensure stakeholder Transparency) berfokus pada transparansi kepada stakeholder organisasi yakni memastikan bahwa adanya transparansi kinerja TI di dalam organisasi serta kesesuaian pengukuran dan pelaporannya; serta mendapat persetujuan dari stakeholder mengenai tujuan, metrik, serta tindakan perbaikan yang diperlukan. Tujuan dari proses EDM05 yakni memastikan bahwa komunikasi dengan para stakeholder aktif dan tepat waktu dengan tujuan dasar pelaporan untuk meningkatkan kinerja, mengidentifikasi area untuk perbaikan, dan mengaskan bahwa tujuan dan strategi yang berkaitan dengan TI sejalan dengan strategi organisasi. Sesuai dengan kondisi saat ini, proses ini tercapai $100 \%$ dan berada di level 5 (optimizing process) serta termasuk kedalam kategori fully achieved. Proses ini dapat tercapai secara tuntas karena adanya peraturan yang mengatur penyelenggaraan tentang hal-hal yang berkaitan dengan prosedur tata kelola TI yang ada di Dukcapil. Sesuai dengan apa yang disampaikan oleh Bapak Syaiful berikut:

"Di Disdukcapil sendiri kami memiliki peraturan yang digunakan sebagai pedoman dalam menjalankan prosedur yang setiap hari terjadi. Dengan menggunakan peraturan tersebut kami dituntut untuk mengikuti peraturan tersebut sebagai urutan dalam melakukan aktivitas kerja kami, oleh sebab itu hampr semua hal yang berkaitan dengan pihak atasan dapat berjalan secara optimal karena semua bekerja sesuai dengan peraturan yang ada. Peraturan tersebut juga tidak bersifat mengekang, tetapi dapat menjadi pedoman dalam menjalankan tugas. Beberapa peraturan yang kami miliki misalnya saja peraturan Gubernur, peraturan daerah, undang-undang ketenagakerjaan, dan masih banyak lagi. Di Disdukcapil sendiri untuk pelaporan hasil kerja pun sudah dilakukan secara terkoordinir, misalnya saja dari bagian pelayanan, karena mereka sudah menggunakan aplikasi dalam menjalankan aktivitas kerja, mereka dapat membuat tutup buku setiap harinya atau bisa dikatakan terdapat data pelayanan yang dibuat secara berkala dan hal tersebut juga untuk mempermudah pekerjaan dan mencegah terjadinya masalah". 6

Dari hasil pengamatan terlihat bahwa tata kelola TI yang berjalan di Disdukcapil sudah berjalan dengan cukup baik. Hal tersebut berbanding terbalik dengan belum optimalnya

\footnotetext{
${ }^{5}$ Berdasarkan hasil wawancara dengan Bapak Syaiful staff umum dan personalia bagian TI pada tanggal 18 September 2019 di Disdukcapil Kota Tangerang

${ }^{6}$ Berdasarkan hasil wawancara dengan Bapak Syaiful staff umum dan personalia bagian TI pada tanggal 18 September 2019 di Disdukcapil Kota Tangerang
} 
penggunaan TI di Disdukcapil, dimana para pegawai belum memahami penggunaan dan pemanfaatan sumberdaya TI yang ada disana. Kebanyakan mereka hanya bertindak sebagai pengguna. Itupun dalam pengoperasiannya belum dilakukan secara menyeluruh. Disdukcapil sendiri memiliki target pencapaian yang diharapkan yaitu mencapai level 5 (optimizing process) .

Dari data di atas masih terdapat kesenjangan, dimana kesenjangan yang terdapat pada masing-masing subdomain tersebut kemudian dianalisis dan didapatkan nilai kesenjangan pada masing - masing subdomain, yaitu pada domain EDM01 sebesar 2.00; EDM02 sebesar 0.75; EDM03 sebesar 1.42; EDM04 sebesar 1.65; dan EDM05 adalah sebesar 0.00. Nilai kesenjangan GAP tersebut merupakan hasil dari selisih target yang diinginkan dengan pencapaian realtime atau saat ini (existing). Penentuan target level tidak mengarah pada perolehan hasil tertinggi maupun terendah, melainkan disesuaikan dengan status level dari oleh proses-proses tersebut. Adapun rata-rata untuk GAP untuk kesatuan utuh domain EDM adalah sebesar 1.16. Nilai ini dapat digunakan untuk melakukan penyesuaian pada masing-masing proses domain.

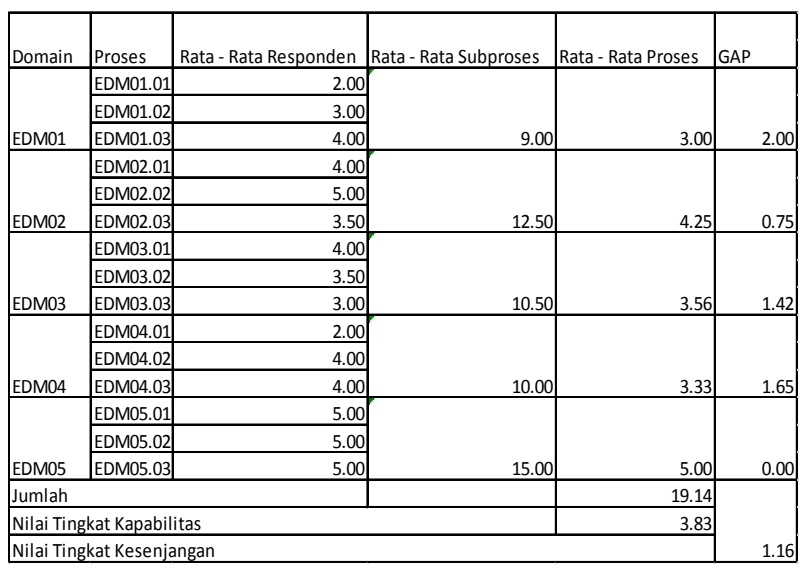

Tabel 1. Rekapitulasi Model Kapabilitas

Berdasarkan pengukuran terhadap level kapabilitas tingkat kematangan tata kelola TI yang ada pada Disdukcapil Kota Tangerang, penulis berpendapat perlu dilakukan perbaikan dalam optimalisasi terhadap aset sumberdaya TI yang ada. Adapun rekomendasi yang dapat diberikan berdasarkan analisis pada domain EDM yang telah dilakukan antara lain:

- Disdukcapil Kota Tangerang perlu membentuk divisi TI agar dapat melakukan pengelolaan TI secara mandiri agar segala aktivitas yang berkaitan dengan TI dapat berjalan secara optimal dan dapat menanggulangi permasalahan terhadap sumber daya TI secara mandiri;

- Disdukcapil Kota Tangerang perlu melakukan pembaharuan terhadap perangkat keras atau hardware yang ada;
- Disdukcapil Kota Tangerang perlu membuat ruangan server yang layak sesuai dengan standar pembangunan server yang baik untuk mengurangi dampak resiko bagi organisasi;

- Disdukcapil Kota Tangerang perlu merekrut pegawai yang berkompeten di bidang TI agar dapat ditugaskan sebagai staff khusus untuk melakukan penanganan dan pengelolaan terhadap sumberdaya TI yang ada;

- Disdukcapil Kota Tangerang perlu melakukan sosialisasi dan pelatihan terhadap sumber daya manusia pengguna teknologi informasi agar dapat memanfaatkan TI dengan baik;

- Disdukcapil Kota Tangerang perlu melakukan pengembangan terhadap sumber daya TI untuk menunjang kinerja perusahaan.

\section{KESIMPULAN}

Melalui evaluasi tingkat kematangan TI pada Disdukcapil Kota Tangerang dengan menggunakan COBIT 5 yang meliputi domain EDM, dapat diambil kesimpulan bahwa tingkat kematangan tata kelola TI di Disdukcapil berada pada level 3 (managed process). Sedangkan tingkat kapabilitas yang didapatkan masih jauh dari target pencapaian yang diinginkan yaitu pada level 5 (optimizing process). Oleh sebab itu Disdukcapil Kota Tangerang perlu melakukan pengembangan terhadap tata kelola TI yang sedang berjalan. Selain itu untuk meningkatkan kualitas sumber daya manusianya Disdukcapil Kota Tangerang juga dapat memberikan pelatihan kepada pegawai guna meningkatkan kinerja TI di Disdukcapil Kota Tangerang.

\section{REFERENSI}

[1]. Hilmawan, Hadi .dkk (2015), Analisis Tata Kelola Teknologi Informasi menggunakan Kerangka Kerja COBIT 5 pada AMIK JTC Semarang. Semarang: Universitas Diponegoro.

[2]. Luqida Aji, Index ,dkk . (2017) , Analisis Tata Kelola Teknologi Informasi di PDAM Kota Salatiga Menggunakan Framework COBIT 5 Dengan Domain EDM. Salatiga: Universitas Kristen Satya Wacana

[3]. Prasojo, Hario Putro dan Pujiono . Analisis Tata Kelola Teknologi Informasi Dengan Menggunakan Framework COBIT 5 Domain DSSO1 (Manage Operations) Pada BPS Provinsi Jawa Tengah. Semarang: Universitas Dian Nuswantoro

[4]. Jogiyanto dan Willy Abdillah, (2011), Sistem Informasi Tata Kelola Teknologi Informasi, Yogyakarta: Andi, diambil dari Jurnal Teknologi Informasi dan Komputer. Maskur,dkk, 2016, Perancangan Tata Kelola TI dengan Menggunakan Framework COBIT 5 (Studi Kasus: 
Pemerintah Kab. Janeponto). Yogyakarta: Universitas Gadjah Mada

[5]. ISACA, (2012), COBIT 5: Framework. Rolling Meadows: USA

[6]. ISACA, (2013), COBIT 5: Process Assesment Model (PAM). Rolling Meadows: USA

[7]. M. P. Islamiah, (2014), Tata Kelola Teknologi Informasi (IT governance) Menggunakan Frmaework COBIT 5 Studi Kasus : Dewan Kehormatan Penyelenggara Pemilu (DKPP). Jakarta: UIN Syarif Hidayatullah. 